\title{
Changes in $\mathrm{O}_{2}^{-}$and $\mathrm{H}_{2} \mathrm{O}_{2}$ production by Chattonella antiqua during diel vertical migration under nutrient stratification
}

\author{
Daekyung Kim ${ }^{1,3,4}$, Masataka Watanabe ${ }^{1, *}$, Yoko Nakayasu $^{1}$, Kunio Kohata ${ }^{2}$ \\ ${ }^{1}$ Water and Soil Environment Division, and ${ }^{2}$ Watershed Environmental Management Group, National Institute for \\ Environmental Studies, Onogawa, Tsukuba, Ibaraki 305-8506, Japan \\ ${ }^{3}$ Japan Society for the Promotion of Science (JSPS), Kojimachi Office Yamato Bldg., 5-3-1 Kojimachi, Chiyoda-ku, \\ Tokyo 102-8471, Japan
}

${ }^{4}$ Present address: Division of Biochemistry, Faculty of Fisheries, Nagasaki University, Bunkyo-machi 1-14, Nagasaki 852-8521, Japan

\begin{abstract}
The red tide flagellate Chattonella antiqua produces high levels of reactive oxygen species (ROS) such as the superoxide anion $\left(\mathrm{O}_{2}^{-}\right)$and hydrogen peroxide $\left(\mathrm{H}_{2} \mathrm{O}_{2}\right)$. Production of ROS by this flagellate species depends on nutrient and water conditions during its growth phases. To clarify the effect of nutrient depletion on ROS production, we investigated the production pattern of ROS in a culture tank containing $1 \mathrm{~m}^{3}$ of medium with low nitrate and phosphate nutrient concentrations. The production of $\mathrm{O}_{2}{ }^{-}$and $\mathrm{H}_{2} \mathrm{O}_{2}$ by $C$. antiqua was lower when nutrients were limited than when they were fully supplied (f/2 medium), as indicated by reductions in nitrogen and phosphorus cell quotas. We also examined ROS formation by $C$. antiqua under stratified conditions subsequent to the nutrient depletion experiment. The vertical stratification of salinity $(\Delta S=2.5 \mathrm{psu})$ and temperature $(\Delta T=$ $5^{\circ} \mathrm{C}$ ) in the tank were analogous to natural conditions during red tides, and only the bottom layer was enriched with nutrients. C. antiqua showed clear diel vertical migration under stratified conditions. The ROS production due to photosynthesis was high during the light period at the surface, even though the ambient nutrient concentration of the surface was low, and it decreased in the dark bottom layer. The generation of $\mathrm{H}_{2} \mathrm{O}_{2}$ increased continuously for $4 \mathrm{~d}$, but $\mathrm{O}_{2}{ }^{-}$generation peaked on the second day of stratification and then gradually decreased.
\end{abstract}

KEY WORDS: Chattonella antiqua - Diel vertical migration $\cdot$ Hydrogen peroxide $\cdot$ Nutrient stratification $\cdot$ Reactive oxygen species $\cdot$ Superoxide anion

\section{INTRODUCTION}

Chattonella antiqua is a dominant red tide-forming phytoplankton species worldwide and causes serious damage to fish farms. The mechanism of ichthyotoxicity of $C$. antiqua is not known in detail, but Chattonella spp. generate reactive oxygen species (ROS) such as the superoxide anion $\left(\mathrm{O}_{2}^{-}\right)$and hydrogen peroxide $\left(\mathrm{H}_{2} \mathrm{O}_{2}\right)$ (Shimada et al. 1991, 1993, Oda et al. 1992, 1995, Tanaka et al. 1992, 1994, Marshall et al. 2002). Since ROS are generally toxic to living organisms (Oda et al. 1989, 1997), those generated by Chattonella spp. may cause gill tissue injury and, eventually, fish death (Kim et al. 2000, 2001).

To understand the ROS production mechanism, it is necessary to investigate ROS production during phytoplankton cell growth phases. Kim et al. (2004) conducted a large-scale tank experiment under light:dark conditions and demonstrated that ROS generation by Chattonella antiqua increased during the light period as a result of photosynthesis and decreased during the dark period. This finding indicated that ROS generation rates were closely related to growth metabolism during the cell division cycle of $C$. antiqua because cell 
division occurred almost once per day during the exponential growth phase (Kim et al. 2004).

Chattonella antiqua is a motile phytoplankton characterized by diel vertical migration (DVM) and nocturnal nutrient uptake (Watanabe et al. 1991). The cells accumulate at the surface during the day for photosynthesis and sink to a deeper layer, where nutrients such as nitrate and phosphate are abundant, to take up the nutrients during the night. Under stratified conditions, the DVM ability gives the cells an ecological advantage over other non-motile phytoplankton species because the surface nutrients are generally almost depleted. The DVM of the flagellate population was examined in a culture tank at the National Institute for Environmental Studies (NIES), Japan (Kohata \& Watanabe 1986, 1987, Watanabe et al. 1991, 1995, Kimura et al. 1999), in terms of nutrition and growth. Kim et al. (2004) suggested that the toxicity induced by ROS was presumably linked to cell migration through the cell cycle and nutrition although their study on ROS generation by $C$. antiqua was conducted in the NIES tank under fully mixed conditions

For the present study, we grew Chattonella antiqua in the NIES culture tank under limited nitrate and phosphate nutrient conditions to clarify the effect of nutrient depletion on ROS production through the growth metabolism during cell division cycles of C. antiqua. After the nutrients became depleted, vertical salinity and temperature stratification was established, and nutrients were enriched only in the bottom layer. These conditions are analogous to those observed under natural conditions during red tides. The purpose of this study was to investigate the effect of nutrient depletion on ROS production by $C$. antiqua and to clarify the relationship between the production of ROS and the uptake of nutrients during DVM under stratified conditions

\section{MATERIALS AND METHODS}

Experimental set-up of the culture tank. A clonal axenic culture strain of Chattonella antiqua (Hada) Ono (NIES-1, NIES Microbial Culture Collection) was precultured as described previously (Kohata \& Watanabe 1988, Kim et al. 2004). The stock culture was maintained in $\mathrm{f} / 2$ medium (Guillard \& Ryther 1962) under $80 \mu \mathrm{mol}$ photons $\mathrm{m}^{-2} \mathrm{~s}^{-1}$ illumination on a 12:12 h light:dark regime. Temperature was kept constant at $23 \pm 1^{\circ} \mathrm{C}$.

A NIES culture tank $(2 \mathrm{~m}$ high, $1 \mathrm{~m}$ internal diameter, working volume about $1 \mathrm{~m}^{3}$, and airspace about $0.4 \mathrm{~m}^{3}$ ) was used to grow Chattonella antiqua under axenic conditions (Kim et al. 2004). Before the experiments, the tank, the air and seawater filters, and all pipes were sterilized with steam $\left(110^{\circ} \mathrm{C}, 0.5 \mathrm{~kg} \mathrm{~cm}{ }^{-2}\right.$ pressure) for $30 \mathrm{~min}$. The tank was then filled with $1 \mathrm{~m}^{3}$ of medium, which was sterilized through 3 levels of filters (final filter, $0.1 \mu \mathrm{m}$ Pall ULTIPOR, N66 Pall). Illumination (12:12 h light:dark) was provided by a daylight $5 \mathrm{~kW}$ xenon lamp with an irradiance of about $525 \mu \mathrm{mol}$ photons $\mathrm{m}^{-2} \mathrm{~s}^{-1}$. The light period was from 06:00 to $18: 00 \mathrm{~h}$.

Culture experiments were conducted under 3 nutrient conditions: (1) a fully supplied medium (FSM, f/2 medium) as a control, (2) a limited nutrient medium (LNM), and (3) a bottom-layer-enriched medium, after stratification had been achieved. The FSM experiment was conducted prior to the other two, and the LNM and stratification experiments were conducted sequentially in the same tank. In the FSM and LNM experiments, the medium was fully mixed by introducing sterilized air, regulated at about $200 \mathrm{ml} \mathrm{min}^{-1}$, as fine bubbles from the bottom of the tank, and vertical mixing by thermal convection was induced by regulating the water temperature in the water jackets, which were used to keep the water temperature in the tank constant at $25 \pm 1^{\circ} \mathrm{C}$. In the LNM experiment, $\mathrm{f} / 2$ medium was used except that the initial concentration of dissolved inorganic phosphate (DIP; as $\mathrm{NaH}_{2} \mathrm{PO}_{4}$. $2 \mathrm{H}_{2} \mathrm{O}$ ) was adjusted to $1.0 \mu \mathrm{M}$, and that of dissolved inorganic nitrogen (DIN; as $\mathrm{NaNO}_{3}$ ) was adjusted to $20 \mu \mathrm{M}$, and salinity was $30.8 \mathrm{psu}$.

A 21 culture of Chattonella antiqua (about 2000 to 3000 cells ml$^{-1}$ ) prepared as described above at the exponential phase of growth was inoculated into the tank to achieve an initial cell concentration on Day 1 of 4.4 cells ml$l^{-1}$ in the FSM and 4.0 cells ml ${ }^{-1}$ in the LNM experiment.

We began the stratification experiment at 14:00 $\mathrm{h}$ on Day 10 (the 10th day after inoculation), which followed the LNM experiment, when the cell concentration was 590 cells ml ${ }^{-1}$ and DIP was $<0.1 \mu \mathrm{mol} \mathrm{l}^{-1}$. When aeration was stopped and water temperature in the regulating jackets was changed to produce stratification, Chattonella antiqua began to accumulate at the surface by vertical migration. Then, $100 \mathrm{l}$ of the bottom water was discharged over a $2 \mathrm{~h}$ period. The next day (Day 11), $100 \mathrm{l}$ of new medium enriched with DIN $(440 \mu \mathrm{M})$ and DIP $(19.3 \mu \mathrm{M})$ and with higher salinity (33.3 psu) was introduced into the bottom of the tank at 17:00 $\mathrm{h}$ to start the migration experiment. It took about $4 \mathrm{~h}$ to replace the bottom water and establish stratification, because the flow rate was regulated at less than $400 \mathrm{ml} \mathrm{min}^{-1}$ to avoid disturbing the interface. Water temperature was controlled at $27 \pm 1^{\circ} \mathrm{C}$ at the surface and $22 \pm 1^{\circ} \mathrm{C}$ in the bottom layer $\left(\Delta T=5^{\circ} \mathrm{C}\right)$. Salinity was 30.8 psu at the surface and 33.3 psu in the bottom layer $(\Delta S=2.5 \mathrm{psu})$. The large differences in salinity and temperature between surface and bottom layers in the tank prevented vertical mixing of the water col- 
umn, and stratification was maintained throughout the migration experiment period regardless of the vertical migration of $C$. antiqua cells. Other experimental details were as described previously (Watanabe et al. 1991, Kim et al. 2004).

Samples were collected from the surface, middle, and bottom levels of the tank throughout the experiments. An aspirator was used for pumping samples to avoid damage to the cells. In the LNM and FSM experiments, 21 water samples were collected once per day at 13:00 $\mathrm{h}$ from the middle level of the tank and used immediately to measure cell concentration, DIP and DIN in the medium, and ROS activities. During the stratification experiment (Days 11 to 16), 21 each of surface and bottom waters were collected at 6 to $12 \mathrm{~h}$ intervals and used immediately to measure cell concentration, DIP and DIN in the medium, particulate carbon, and ROS activities.

Analytical methods. Cells were counted 3 times for each sample with a Coulter Multisizer II (Coulter Electronics). For particulate carbon and nitrogen measurements, part of the sampled water $(500 \mathrm{ml})$ was filtered through precombusted $\left(450^{\circ} \mathrm{C}\right.$ for $\left.4 \mathrm{~h}\right)$ Whatman GF/F $47 \mathrm{~mm}$ glass-microfibre filters (Whatman International). The filters were rinsed with $0.5 \mathrm{M}$ ammonium formate and stored at $-20^{\circ} \mathrm{C}$ until analysis (Watanabe et al. 1991, Kimura et al. 1999, Kim et al. 2004). After the filters had been dried in a forced-air oven at $80^{\circ} \mathrm{C}$ for $48 \mathrm{~h}$, we measured particulate carbon and nitrogen on the filters with a CHN analyzer (MT-3, Yanaco; Kohata \& Watanabe 1988). The DIP (as $\left.\mathrm{PO}_{4}{ }^{3-}\right)$ and the DIN (as $\mathrm{NO}_{3}{ }^{-}$) concentrations were analysed using the method of Murphy \& Riley (1962) with a TRAACS 800 analyzer (Bran + Luebbe Corporation).

Measurements of $\mathrm{O}_{2}{ }^{-}$. To detect the $\mathrm{O}_{2}{ }^{-}$produced by Chattonella antiqua, we used 2-methyl-6(p-

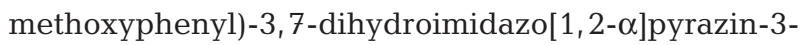
one (MCLA) as a superoxide-specific chemiluminescent probe, as previously described (Lee et al. 1995, Oda et al. 1998). MCLA was dissolved in distilled water and stored at $-30^{\circ} \mathrm{C}$ until use. MCLA was added to a cell suspension, and the chemiluminescence response was recorded immediately with a Luminoskan TL Plus (Thermo Labsystems). The amount of $\mathrm{O}_{2}{ }^{-}$generation detected by chemiluminescence responses was distinguishably high during the first $30 \mathrm{~s}$ of exposure, so the readings of the responses were accumulated for that time period (Nakamura et al. 1998). Typical reaction mixtures comprised $500 \mu \mathrm{l}$ of cell suspension, $166 \mu \mathrm{l}$ of MCLA solution (final concentration, $5 \mu \mathrm{g} \mathrm{ml}^{-1}$ ), and $15 \mu \mathrm{l}$ of $\mathrm{f} / 2$ medium. Reagent background was measured with the same reaction mixture except that $15 \mu \mathrm{l}$ of superoxide dismutase (SOD; final concentration, 100 units $\mathrm{ml}^{-1}$ ) was used instead of $15 \mu \mathrm{l}$ of $\mathrm{f} / 2$ medium at the beginning of every sampling time. MCLA produced a slight chemiluminescence response in $\mathrm{f} / 2$ medium, but a similar level of response was also observed in distilled water under the same experimental conditions. Therefore, the value in $\mathrm{f} / 2$ medium without cell suspension was subtracted from each value as non-specific background. All chemiluminescence analyses were done immediately after the sampling in triplicate at $27^{\circ} \mathrm{C}$.

Measurement of $\mathbf{H}_{2} \mathbf{O}_{2} \cdot \mathrm{H}_{2} \mathrm{O}_{2}$ was detected by a $p$ hydroxyphenylacetate (PHPA) assay (Hyslop \& Sklar 1984) within $1 \mathrm{~h}$ after the sampling for triplicate samples at $27^{\circ} \mathrm{C}$. After the addition of PHPA (final concentration, $1 \mathrm{mM}$ ) and horseradish peroxidase (final concentration, $100 \mathrm{mg} \mathrm{ml}^{-1}$ ) to the cell suspension in $\mathrm{f} / 2$ medium, the increase in fluorescence intensity during the first minute of incubation was measured with a fluorescence spectrophotometer (Shimadzu RF-540) at an excitation wavelength of $317 \mathrm{~nm}$ and an emission wavelength of $400 \mathrm{~nm}$ in the presence or absence of 500 units $\mathrm{ml}^{-1}$ catalase. The catalase-inhibited increase in fluorescence was considered to represent actual $\mathrm{H}_{2} \mathrm{O}_{2}$. The production of $\mathrm{H}_{2} \mathrm{O}_{2}$ was estimated using a standard curve of $\mathrm{H}_{2} \mathrm{O}_{2}$ in cell-free $\mathrm{f} / 2$ medium. The standard solution of $\mathrm{H}_{2} \mathrm{O}_{2}$ in $\mathrm{f} / 2$ medium was prepared from reagent-grade $\mathrm{H}_{2} \mathrm{O}_{2}$ (Santoku Chemical Industries). Under these assay conditions, the increase in fluorescence was proportional to the production of $\mathrm{H}_{2} \mathrm{O}_{2}$ (Zhou et al. 1997).

\section{RESULTS}

\section{Effect of nutrient depletion on $\mathrm{O}_{2}{ }^{-}$and $\mathrm{H}_{2} \mathrm{O}_{2}$ production during growth phases}

To elucidate the effect of nutrient depletion on $\mathrm{O}_{2}{ }^{-}$ and $\mathrm{H}_{2} \mathrm{O}_{2}$ production, cell growth, $\mathrm{O}_{2}^{-}$production, and $\mathrm{H}_{2} \mathrm{O}_{2}$ production of Chattonella antiqua cells grown in LNM were compared with those of cells grown in FSM (Fig. 1). $\mathrm{O}_{2}^{-}$and $\mathrm{H}_{2} \mathrm{O}_{2}$ activities in LNM were weak, whereas those in FSM increased with cell growth (Fig. 1B,C). After inoculation of cells into the tank, growth was measured by counting live cells at $1 \mathrm{~d}$ intervals. The specific growth rate $(\mu)$ was calculated from the cell density changes (Kohata \& Watanabe 1988). The values were averaged over Days 6 and 10 when the cell quota in LNM was lower than that in FSM as described below, being $0.57 \mathrm{~d}^{-1}$ for FSM and $0.51 \mathrm{~d}^{-1}$ for LNM. Averaged values were close to $0.67 \mathrm{~d}^{-1}$ that was obtained during the exponential growth phase under a good-growth condition in the same tank (Kohata \& Watanabe 1988). The $\mathrm{pH}$ increased from 8.09 to 8.65 from the beginning of the LNM experiment to Day 10, showing that the air bubble from the bottom of the tank supplied sufficient air to cell growth. Ambient nutrient concentrations in 

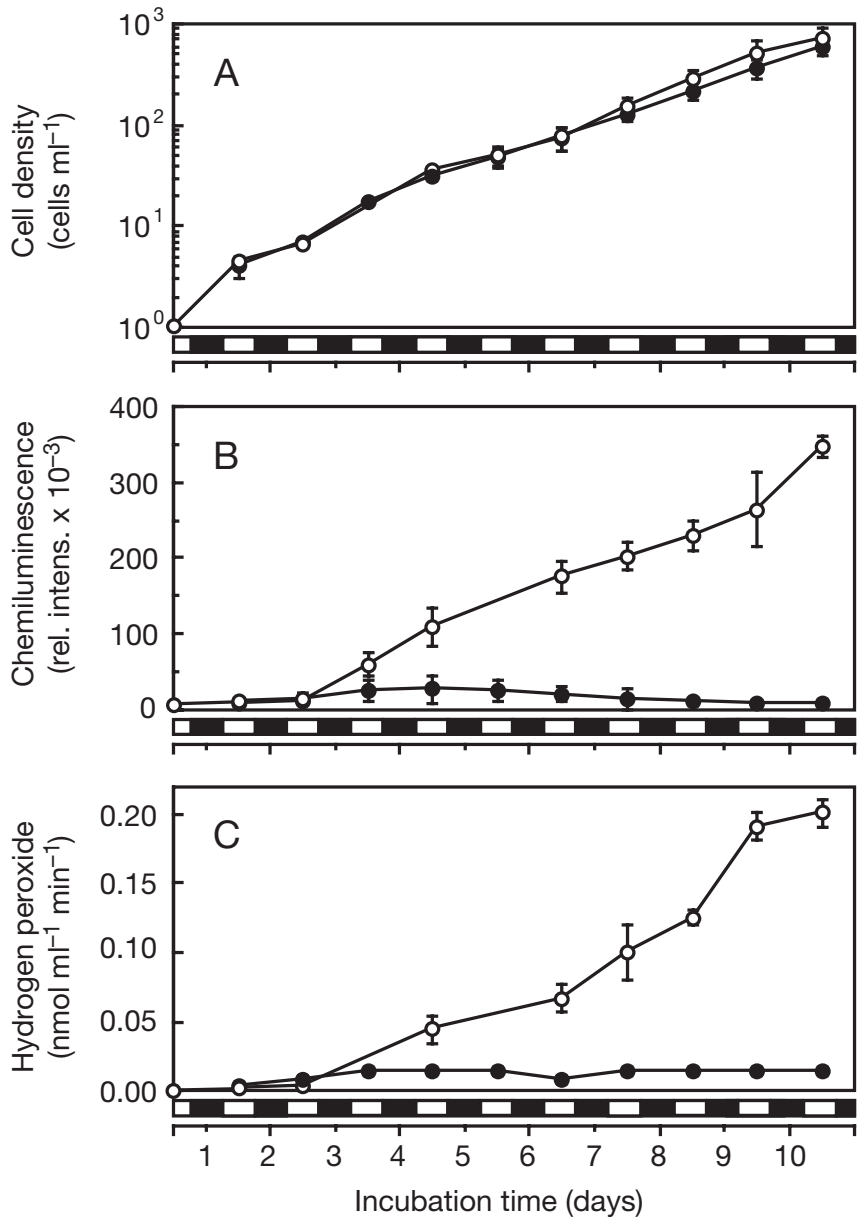

Fig. 1. Chattonella antiqua. Cell growth, superoxide anion $\left(\mathrm{O}_{2}^{-}\right)$generation, and production of hydrogen peroxide $\left(\mathrm{H}_{2} \mathrm{O}_{2}\right)$ between cells grown under the fully supplied (O) and limitednutrient $(\bullet)$ culture conditions in the National Institute for Environmental Studies tank. (A) Cell densities, (B) $\mathrm{O}_{2}{ }^{-}$generation detected by chemiluminescence responses, and (C) production of $\mathrm{H}_{2} \mathrm{O}_{2}$. Vertical bars in the figure are standard deviations of triplicate measurements $(N=3 \pm \mathrm{SD})$. The black and white segments on the lower bars indicate dark and light periods, respectively, during the 12:12 h light:dark cycle

LNM decreased from initial DIN and DIP concentrations of 18.1 and $0.6 \mu \mathrm{M} \mathrm{l}^{-1}$ to 4.7 and $0.05 \mathrm{\mu M} \mathrm{l}^{-1}$ on Day 10, respectively (Fig. 2), during the cell growth phase. DIP decreased gradually from the first day, but DIN was relatively constant until Day 7 , when it began to decrease steeply. The concentration of DIP in the medium was completely depleted below detection limit by Day 9 (Fig. 2B), but the cell density continued to increase (Fig. 1A). We also calculated the daily changes in nitrogen and phosphorus quotas of $C$. antiqua cells by dividing the decrease in ambient nutrient concentration by cell density during cell growth. The nitrogen and phosphorus cell quotas decreased to 22 and 1.2 pmol cell $^{-1}$, respectively (Fig. 3).
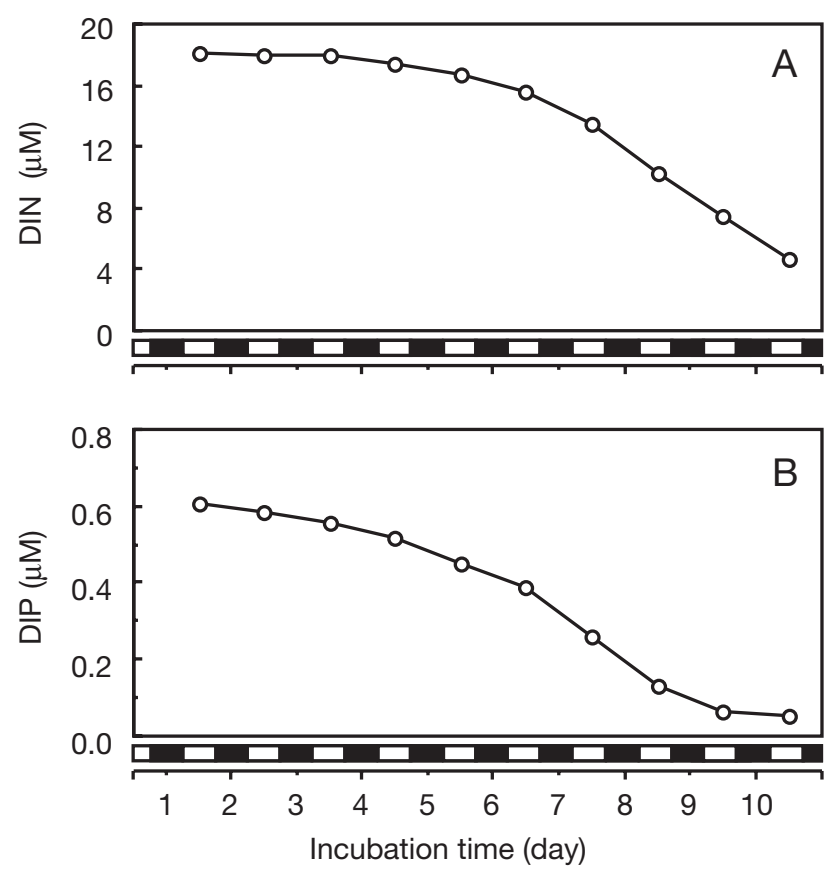

Fig. 2. (A) Ambient dissolved inorganic nitrogen (DIN) and (B) dissolved inorganic phosphate (DIP) concentrations in the liquid nutrient medium of Chattonella antiqua grown under nutrient-limited conditions. The black and white segments on the lower bars indicate dark and light periods, respectively, during the 12:12 h light:dark cycle
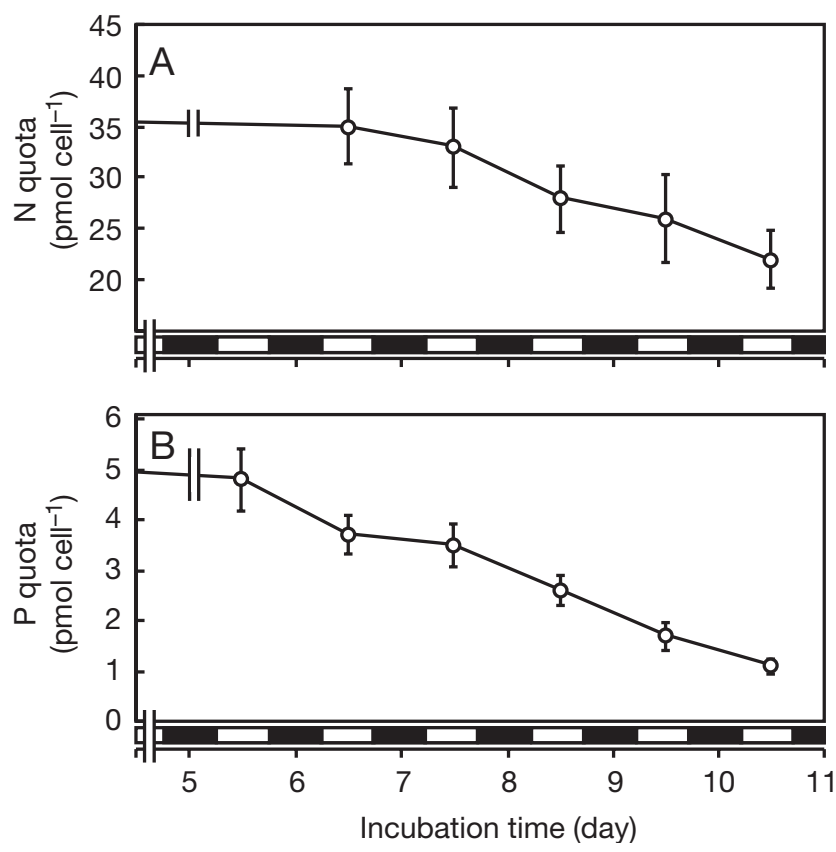

Fig. 3. Chattonella antiqua. (A) Nitrogen and (B) phosphorus cell quotas of cells grown under nutrient-limited conditions. $N=3 \pm \mathrm{SD}$. The black and white segments on the lower bars indicate dark and light periods, respectively, during the 12:12 h light:dark cycle 


\section{ROS activities during diel vertical migration}

At the beginning of the stratification experiment, nutrient-rich seawater with high salinity was introduced into the bottom layer. The DIN and DIP in the bottom layer reached peak values of 392 and $15.4 \mu \mathrm{M}$, respectively, at 17:00 h on Day 11 (Fig. 4), which was when the stratification became established in the tank. Under the stratified conditions, Chattonella antiqua cells began to move downward before the lights were turned off and formed a dense layer on the bottom of the tank. The cells of low $\mathrm{N}$ cell quota reached the nutrient-rich bottom layer and took up nutrients such as DIN and DIP rapidly, thus decreasing nutrient concentrations in the bottom layer (Fig. 4).

The timing of ascending migration and cell division by Chattonella antiqua overlapped. The cells accumulated in the surface layer (Fig. 5A) during the daytime, when cell density at the surface was $5.9 \times 10^{3} \mathrm{cells} \mathrm{ml}^{-1}$, or about 2.4 times that observed during the stationary phase in the NIES tank (Kohata \& Watanabe 1988, Kim et al. 2004). Particulate carbon of $C$. antiqua cells changed similarly to cell density (Fig. 5A,B).

$\mathrm{O}_{2}^{-}$and $\mathrm{H}_{2} \mathrm{O}_{2}$ production by Chattonella antiqua was monitored under stratified conditions to investi-
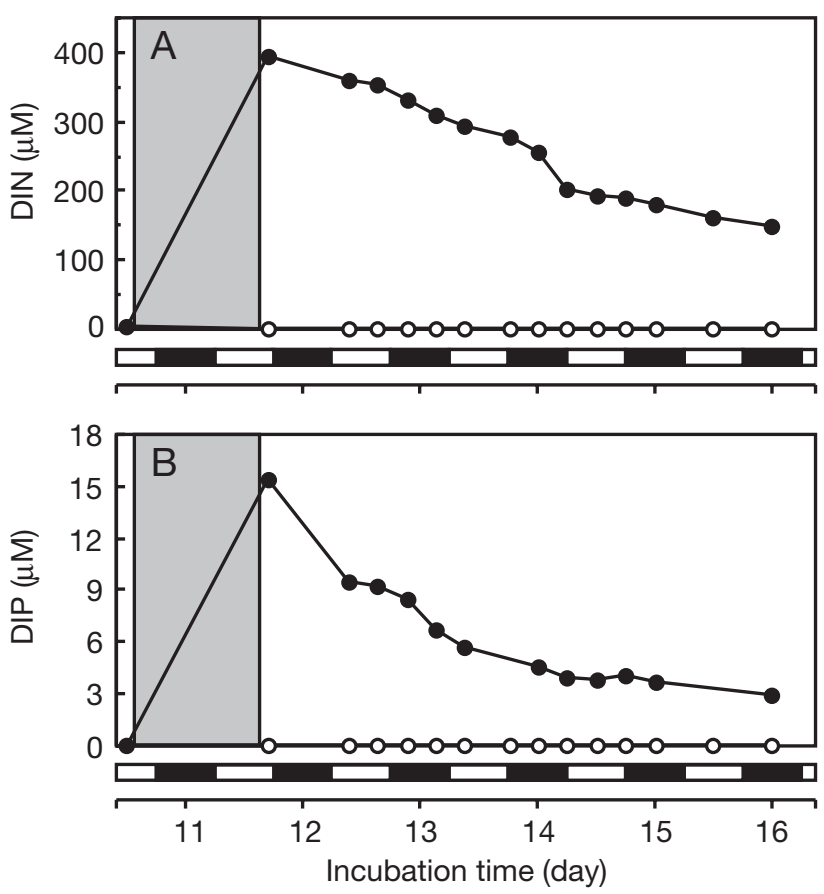

Fig. 4. (A) Dissolved inorganic nitrogen (DIN) and (B) dissolved inorganic phosphate (DIP) concentrations at the surface $(O)$ and in the bottom $(\bullet)$ layer under stratified conditions. Shaded areas denote the period during which stratification was being established. The black and white segments on the lower bars indicate dark and light periods, respectively, during the 12:12 h light:dark cycle gate the production pattern during DVM. The intensity of the chemiluminescence response of $\mathrm{O}_{2}{ }^{-}$and the production of $\mathrm{H}_{2} \mathrm{O}_{2}$ generally recovered from the lowest values in LNM after nutrients were added to the bottom layer (Fig. 5C,D). However, the time of maximum production of $\mathrm{O}_{2}^{-}$and $\mathrm{H}_{2} \mathrm{O}_{2}$ was markedly different between the surface and bottom layers; both $\mathrm{O}_{2}^{-}$and $\mathrm{H}_{2} \mathrm{O}_{2}$ production were high during the light period and low during the dark period in the surface
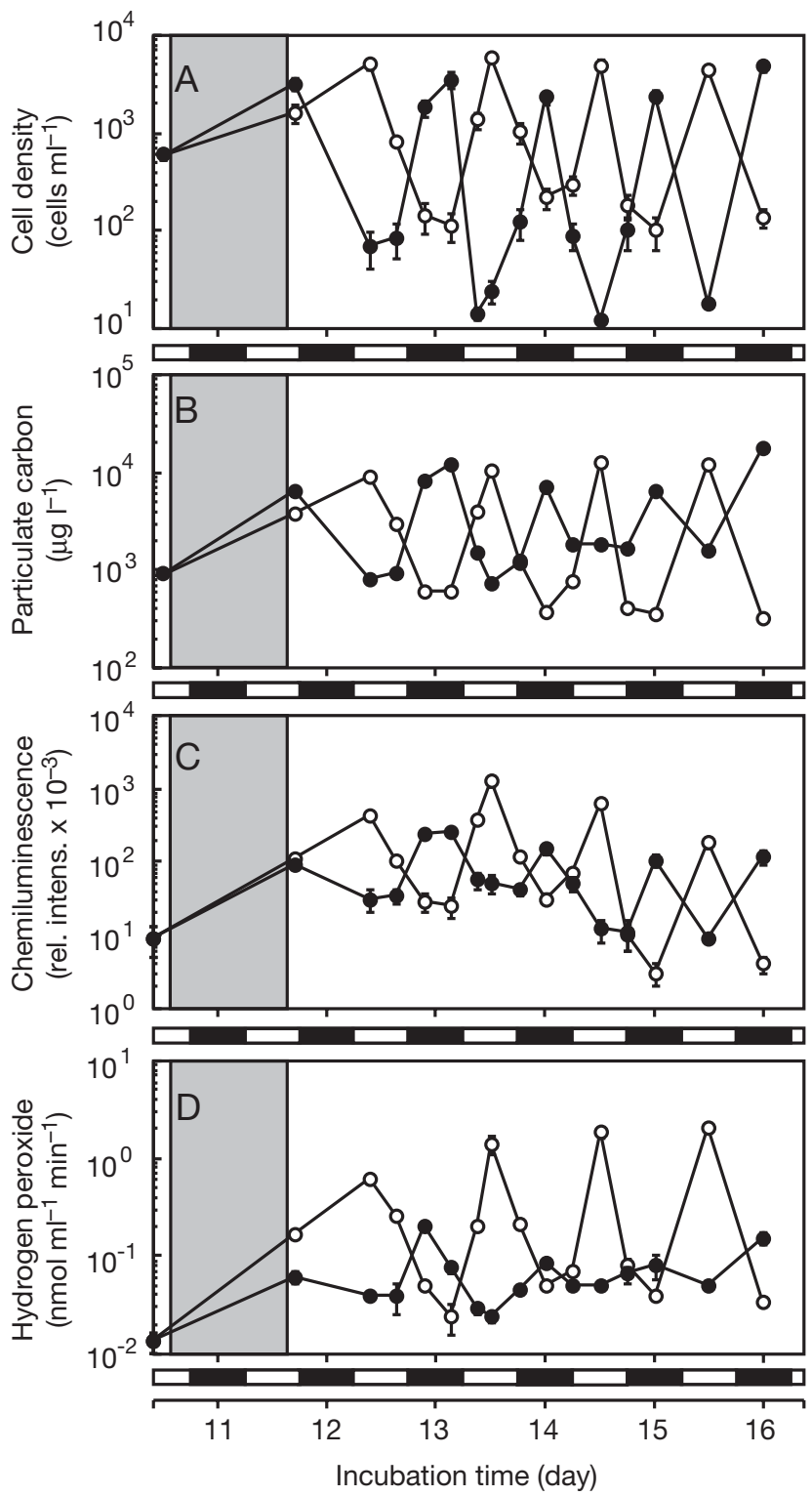

Fig. 5. Chattonella antiqua. Vertical distribution of (A) cell densities, (B) particulate carbon, (C) $\mathrm{O}_{2}{ }^{-}$production, and (D) $\mathrm{H}_{2} \mathrm{O}_{2}$ production under stratified conditions at the surface (O) and in the bottom ( $($ ) layer. Shaded areas denote the period during which stratification was being established. The black and white segments on the lower bars indicate dark and light periods, respectively, during the 12:12 h light:dark cycle. $N=3 \pm \mathrm{SD}$ for (A), (C), and (D); $N=1$ for (B) 
layer (Fig. 5C,D), reflecting the DVM shown by the cell density and carbon content changes (Fig. 5A,B). The daytime production of $\mathrm{O}_{2}^{-}$in the surface layer reached maximum values on Day 13 and decreased thereafter, whereas daytime $\mathrm{H}_{2} \mathrm{O}_{2}$ production in the surface layer gradually increased during DVM (Fig. 5C,D).

The changes in ROS generating activities shown by $\mathrm{O}_{2}{ }^{-}$and $\mathrm{H}_{2} \mathrm{O}_{2}$ production in the surface and bottom layers were normalized by dividing the total activity by the particulate carbon value to obtain the generation per particulate carbon content (GPC) so that we could compare the ROS production during DVM independent of changes in cell density. The GPC values for $\mathrm{O}_{2}^{-}$ and $\mathrm{H}_{2} \mathrm{O}_{2}$ changed in clearly different ways during DVM (Fig. 6). The GPC value for $\mathrm{O}_{2}^{-}$was sometimes higher in the surface layer than in the bottom layer. Both values reached a maximum on Day 13 and decreased thereafter. However, the GPC of $\mathrm{H}_{2} \mathrm{O}_{2}$ in the surface layer was always greater than that in the bottom layer. The surface GPC of $\mathrm{H}_{2} \mathrm{O}_{2}$ showed clear diel changes, with local peaks at 19:00 h on Days 13 and 14, and the daytime values tended to increase during the experimental period (Fig. 6B).

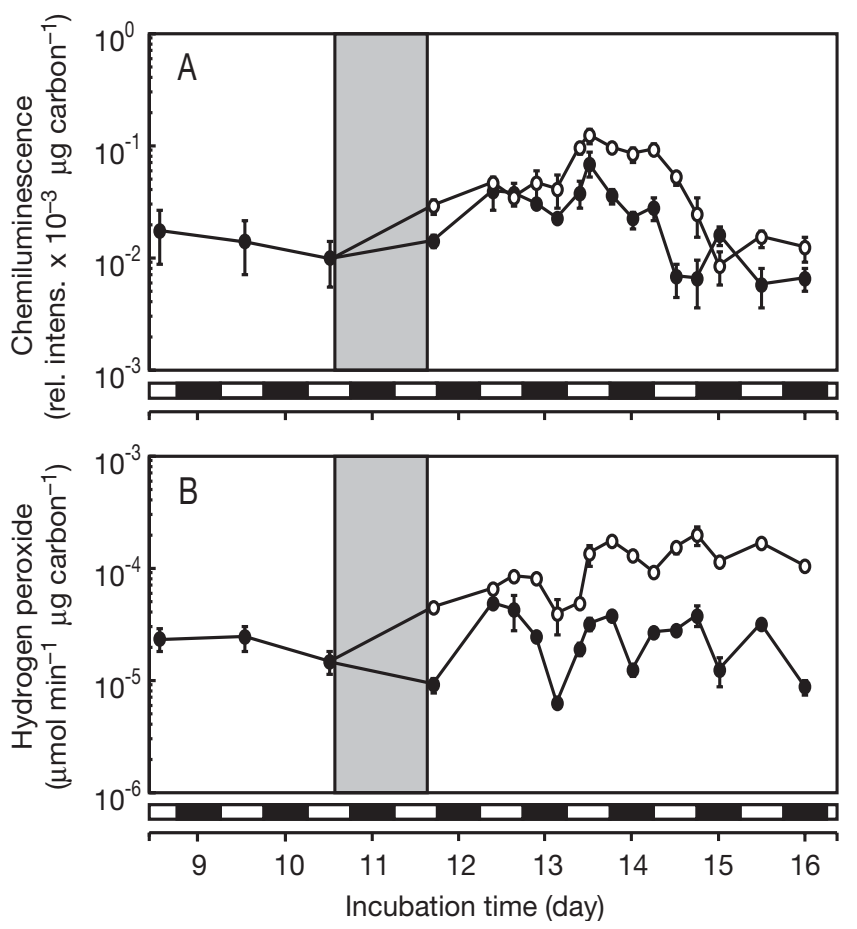

Fig. 6. Generation per particulate carbon content (GPC) values for (A) $\mathrm{O}_{2}{ }^{-}$and (B) $\mathrm{H}_{2} \mathrm{O}_{2}$ of Chattonella antiqua in the surface $(\mathrm{O})$ and bottom $(\bullet)$ layers under stratified culture conditions. Shaded areas denote the period during which stratification was being established. The black and white segments on the lower bars indicate dark and light periods, respectively, during the 12:12 h light:dark cycle

\section{DISCUSSION}

Chattonella antiqua cells grown in LNM had lower nitrogen and phosphorus cell quotas and weak $\mathrm{O}_{2}{ }^{-}$and $\mathrm{H}_{2} \mathrm{O}_{2}$ responses during the growth phase, showing that nutrient depletion negatively affected ROS production (Figs. 1 \& 3). Cell growth kinetics have been intensively analysed as functions of ambient nutrient concentrations (e.g. Dugdale 1967) and cell quotas (e.g. Droop 1973, Amano et al. 1998). In most cell-quota growth models, the cell quota depends on the nutrient uptake rate, which is a function of ambient nutrient concentrations. A typical uptake function is a Monod-type equation, which has a half-saturation constant as a control parameter (Nakamura 1985a,b). We regulated the initial phosphate concentration in the tank in LNM at lower than the halfsaturation constant of $C$. antiqua $(1.9 \mu \mathrm{M}$ for phosphate, Nakamura 1985b) to reduce the uptake rate (Fig. 2B). The minimum cell quota, at which phytoplankton cells cease growing, of $C$. antiqua is $11.0 \mathrm{pmol} \mathrm{cell}^{-1}$ for nitrogen and $1.0 \mathrm{pmol} \mathrm{cell}^{-1}$ for phosphorus, determined from semicontinuous culture experiments (Nakamura \& Watanabe 1983). Although the difference between the specific growth rates of $C$. antiqua in LNM $\left(0.51 \mathrm{~d}^{-1}\right)$ and in FSM $\left(0.57 \mathrm{~d}^{-1}\right)$ was small (Fig. $\left.1 \mathrm{~A}\right)$, the $\mathrm{N}$ and $\mathrm{P}$ cell quotas in LNM decreased to minimum cell quota (Fig. 3), indicating that the physiological conditions of flagellate cells in LNM differed from those in FSM. The N and $\mathrm{P}$ cell quotas in FSM remained almost constant at around 37 and $5.5 \mathrm{pmol} \mathrm{cell}^{-1}$, respectively (data not shown). The effect of nutrient depletion was also observed in cell size changes of $C$. antiqua. Cell size (estimated diameter as sphere) in LNM decreased gradually from $36.3 \mu \mathrm{m}$ at the beginning to $30.8 \mu \mathrm{m}$ on Day 10 of the LNM experiment in the tank, but values in FSM were relatively constant (36.5 $\pm 1 \mu \mathrm{m})$ during cell growth (data not shown).

Generally, energy generation in biological organisms requires uptake of both nitrogen and phosphorus. Nitrogen is required for synthesis of various biomolecules, and phosphorus is used in the oxidative reaction of fuel molecules during the synthesis. During biosynthesis, ATP and NADPH are generated as electrons flow from the reduced forms of these carriers to $\mathrm{O}_{2}$. In particular, the partly reduced form, $\mathrm{O}_{2}^{-}$, is generated. The generation of ROS is one of the earliest events in the positive control of cell growth in response to growth factors under growth-promoting conditions (Murrell et al. 1990, Shibanuma et al. 1990). Furthermore, the negative effect of nutrient depletion on ROS production was confirmed by its recovery when the cells were placed in a nutrient-rich medium (Fig. 5C,D).

Night-time nitrogen uptake has been observed in a natural phytoplankton population dominated by dinoflagellates (Cullen \& Horrigan 1981), and dinoflagel- 
lates forming blooms in stratified waters are able to increase their population by nitrogen uptake at depth at night and photosynthesis near the surface during the day through DVM (Dortch \& Maske 1982). In the present study, we also found both DVM and nocturnal uptake of nutrients by Chattonella antiqua in the culture tank, when vertical stratification of nitrogen and phosphorus was established. Both DIN and DIP clearly decreased over time in the bottom layer under stratified conditions (Fig. 4). Because C. antiqua migrates vertically, ascending to the surface photic layer during the day and descending to deeper layers at night, the cells can access nutrients provided that the nutricline is shallower than the depth to which they descend (Fig. 5A). DVM and nocturnal nutrient uptake by C. antiqua were shown experimentally by Watanabe et al. (1991). They also suggested that DVM was the most important factor affecting the dominance of $C$. antiqua from the observation in an enclosure in the Seto Inland Sea, Japan (Watanabe et al. 1995).

The higher ROS production during the daytime could be due to photosynthesis in the surface layer under stable stratification (Fig. 5). This diel pattern in ROS production is similar to the results obtained previously under fully mixed conditions in the same tank (Kim et al. 2004). The sharp daytime peaks in ROS production (Fig. 5C,D) reflected cell accumulations at the surface. The GPC, which is independent of changes in cell density, of $\mathrm{O}_{2}^{-}$reached a maximum during the daytime on Day 13. The GPC of $\mathrm{H}_{2} \mathrm{O}_{2}$ reached local maxima at 19:00 h on Days 13 and 14. Although the detailed mechanisms of ROS production by flagellate cells is unknown, various chemical reactions in higher plants occur during photosynthesis to form $\mathrm{O}_{2}^{-}, \mathrm{H}_{2} \mathrm{O}_{2}$, and $\cdot \mathrm{OH}$ (Halliwell \& Gutteridge 1984). Kim et al. (2004) documented that, similar to higher plants, under fully mixed conditions ROS production by Chattonella antiqua was affected by photosynthesis; in addition, they showed that ROS production expressed as GPC was relatively high in the daytime and decreased at night. The results obtained under stratified conditions showed the same diel trend in ROS production, indicating that ROS production is strongly related to photosynthetic processes.

The PHPA method provides absolute production for $\mathrm{H}_{2} \mathrm{O}_{2}$, the most stable ROS, and enables us to compare data sets obtained under different conditions. The GPC for $\mathrm{H}_{2} \mathrm{O}_{2}$ of Chattonella antiqua was higher at the surface than in the bottom layer. ROS production by the cells remaining in the bottom layer during the day was low (Fig. 6) because these cells can be considered to be less active. In contrast, the GPC for $\mathrm{H}_{2} \mathrm{O}_{2}$ of migrating cells ranged between 0.01 and $0.20 \mathrm{nmol} \mathrm{m^{-1 }} \mu \mathrm{g}$ carbon $^{-1}$ (Fig. 6), which corresponded to the diel changes under fully mixed conditions (0.04 to $0.24 \mathrm{nmol} \mathrm{min}^{-1}$ $\mu \mathrm{g}$ carbon $^{-1}$; Kim et al. 2004). These results suggest that the toxicity induced by $\mathrm{H}_{2} \mathrm{O}_{2}$ production is linked to cell migration through the cell cycle and nutrition.

The $\mathrm{O}_{2}^{-}$and $\mathrm{H}_{2} \mathrm{O}_{2}$ production in the surface recovered from relatively low levels after nutrients were added to the bottom layer under stratified conditions (Fig. 5C,D). However, the pattern of $\mathrm{O}_{2}^{-}$production was different from that of $\mathrm{H}_{2} \mathrm{O}_{2}$ production in the surface layer. Daytime $\mathrm{O}_{2}^{-}$production peaked on Day 13 and decreased thereafter, whereas daytime $\mathrm{H}_{2} \mathrm{O}_{2}$ production increased throughout the experimental period. Kim et al. (2004) reported that $\mathrm{O}_{2}^{-}$production by Chattonella antiqua reached a maximum during the exponential growth phase and decreased subsequently during the stationary phase; the maximum $\mathrm{H}_{2} \mathrm{O}_{2}$ generation occurred during the early stationary growth phase. They also showed that GPC values for $\mathrm{H}_{2} \mathrm{O}_{2}$ during the stationary phase were similar to those obtained during the exponential phase. However, the GPC values for $\mathrm{O}_{2}^{-}$during the stationary phase were clearly lower than during the exponential phase. Under stratified conditions, $\mathrm{pH}$ was more than 8.6 at the surface, which is similar to the $\mathrm{pH}$ during the early stationary growth phase in the fully mixed experiment (Kim et al. 2004). Thus, growth conditions at the surface during the stratified experiment resembled those of the early stationary phase during the fully mixed experiment. Both $\mathrm{O}_{2}^{-}$and $\mathrm{H}_{2} \mathrm{O}_{2}$ production by actively migrating cells are consistent with those observed during the fully mixed experiment with respect to both their pattern of change and their magnitude when this resemblance is taken into account.

In conclusion, our results demonstrate that: (1) ROS generation such as $\mathrm{O}_{2}^{-}$and $\mathrm{H}_{2} \mathrm{O}_{2}$ production by Chattonella antiqua is affected by nutrient availability during cell growth phases; (2) $\mathrm{ROS}\left(\mathrm{O}_{2}{ }^{-}\right.$and $\left.\mathrm{H}_{2} \mathrm{O}_{2}\right)$ production by $C$. antiqua under nutrient stratified conditions was high in the daytime, suggesting that ROS production is related to photosynthetic processes; and (3) C. antiqua cells accumulated at the surface during diel migration resembled those in early stationary phases under fully mixed conditions with respect to both the patterns of change and GPC values of $\mathrm{O}_{2}{ }^{-}$and $\mathrm{H}_{2} \mathrm{O}_{2}$.

Despite many investigations of the growth response of phytoplankton to limited nutrient conditions (Cullen \& Horrigan 1981, Paasche et al. 1984, Cullen 1985, Watanabe et al. 1991), little information has been available on the effect of nutrient depletion on ROS production. The present investigation clarifies the relationship between growth and ROS production under both nutrient-depleted conditions and nutrient stratification. Ichthyotoxicity of Chattonella antiqua under natural conditions may be caused by phenomena similar to our observations on ROS production by $C$. antiqua under experimental stratified conditions. 
Acknowledgements. We thank Professor T. Oda (Faculty of Fisheries, Nagasaki University, Japan) for many helpful comments throughout this work.

\section{LITERATURE CITED}

Amano K, Watanabe M, Kohata K, Harada S (1998) Conditions necessary for Chattonella antiqua red tide outbreaks. Limnol Oceanogr 43:117-128

Cullen JJ (1985) Diel vertical migration by dinoflagellates: roles of carbohydrate metabolism and behavioral flexibility. Mar Sci (Suppl) 27:135-152

Cullen JJ, Horrigan SG (1981) Effects of nitrate on the diurnal vertical migration, carbon to nitrogen ratio, and the photosynthetic capacity of the dinoflagellate Gymnodinium splendens. Mar Biol 62:81-89

Dortch Q, Maske H (1982) Dark uptake of nitrate and nitrate reductase activity of a red-tide population off Peru. Mar Ecol Prog Ser 9:299-303

Droop MR (1973) Some thoughts on nutrient limitation in algae. J Phycol 9:264-272

Dugdale RC (1967) Nutrient limitation in the sea: dynamics, identification, and significance. Limnol Oceanogr 12: 685-695

Guillard RRL, Ryther JH (1962) Studies of marine planktonic diatoms. 1. Cyclotella nana Hustedt and Detonula confervacea (Cleve) Gran. Can J Microbiol 8:229-239

Halliwell B, Gutteridge JMC (1984) Oxygen toxicity, oxygen radicals, transition metals and disease. Biochem $\mathrm{J}$ 219: $1-14$

Hyslop PA, Sklar LA (1984) A quantitative fluorimetric assay for the determination by polymorphonuclear leukocytes: its use in the simultaneous fluorimetric assay of cellular activation processes. Anal Biochem 141:280-286

Kim D, Nakamura A, Okamoto T, Komatsu N, Oda T, Iida T, Ishimatsu A, Muramatsu T (2000) Mechanism of superoxide anion generation in the toxic red tide phytoplankton Chattonella marina: possible involvement of $\mathrm{NAD}(\mathrm{P}) \mathrm{H}$ oxidase. Biochim Biophys Acta 1524:220-227

Kim D, Okamoto T, Oda T, Tachibana K and 5 others (2001) Possible involvement of the glycocalyx in the ichthyotoxicity of Chattonella marina (Raphidophyceae): immunological approach using antiserum against cell surface structures of the flagellate. Mar Biol 139:625-632

Kim D, Watanabe M, Nakayasu Y, Kohata K (2004) Production of superoxide anion and hydrogen peroxide associated with cell growth of Chattonella antiqua. Aquat Microb Ecol 35:57-64

Kimura T, Watanabe M, Kohata K, Sudo R (1999) Phosphate metabolism during diel vertical migration in the raphidophycean alga, Chattonella antiqua. J Appl Phycol 11: 301-311

Kohata K, Watanabe M (1986) Synchronous division and the pattern of diel vertical migration of Heterosigma akashiwo (Hada) Hada (Raphidophyceae) in a laboratory culture tank. J Exp Mar Biol Ecol 100:209-224

Kohata K, Watanabe M (1987) The use of a controlled experimental ecosystem (microcosm) in studies of the mechanism of red tide outbreaks (VII): growth and its mathematical model of Heterosigma akashiwo, a red tide flagellate, in light-limited synchronous cultures. Res Rep Natl Inst Environ Stud 110:79-88 (in Japanese)

Kohata K, Watanabe M (1988) Diel changes in the composition of photosynthetic pigments and cellular carbon and nitrogen in Chattonella antiqua (Raphidophyceae). J Phycol 24:58-66
Lee TY, Goto N, Niki E, Yokoyama K, Tsuzuki M, Takeuchi T, Karube I (1995) Chemiluminescence detection of red tide phytoplankton Chattonella marina. Anal Biochem 67: 225-228

Marshall JA, Hovenden M, Oda T, Hallegraeff GM (2002) Photosynthesis does influence superoxide production in the ichthyotoxic alga Chattonella marina (Raphidophyceae). J Plankton Res 24:1231-1236

Murphy J, Riley JP (1962) A modified single solution method for the determination of phosphate in natural waters. Anal Chim Acta 27:31-36

Murrell GAC, Francis MJO, Bromley L (1990) Modulation of fibroblast proliferation by oxygen free-radicals. Biochem $\mathrm{J}$ 265:659-665

Nakamura A, Okamoto T, Komatsu N, Ooka S, Oda T, Ishimatsu A, Muramatsu T (1998) Fish mucus stimulates the generation of superoxide anion by Chattonella marina and Heterosigma akashiwo. Fish Sci 64:866-869

Nakamura Y (1985a) Ammonium uptake kinetics and interactions between nitrate and ammonium uptake in Chattonella antiqua. J Oceanogr Soc Jpn 41:33-38

Nakamura Y (1985b) Kinetics of nitrogen- or phosphoruslimited growth and effects of growth conditions on nutrient uptake in Chattonella antiqua. J Oceanogr Soc Jpn 41: 381-387

Nakamura Y, Watanabe MM (1983) Growth characteristics of Chattonella antiqua (Raphidophyceae). Part 2. Effects of nutrients on growth. J Oceanogr Soc Jpn 39:151-155

Oda T, Akaike T, Hamamoto T, Suzuki F, Hirano T, Maeda H (1989) Oxygen radicals in influenza-induced pathogenesis and treatment with pyran polymer conjugated SOD. Science 244:974-976

Oda T, Ishimatsu A, Shimada M, Takeshita S, Muramatsu T (1992) Oxygen-radical-mediated toxic effects of the red tide flagellate Chattonella marina on Vibrio alginolyticus. Mar Biol 112:505-509

Oda T, Moritomi J, Kawano I, Hamaguchi S, Ishimatsu A, Muramatsu T (1995) Catalase- and superoxide dismutaseinduced morphological changes and growth inhibition in the red tide phytoplankton Chattonella marina. Biosci Biotechnol Biochem 59:2044-2048

Oda T, Nakamura A, Shikayama M, Kawano I, Ishimatsu A, Muramatsu T (1997) Generation of reactive oxygen species by raphidophycean phytoplankton. Biosci Biotechnol Biochem 61:1658-1662

Oda T, Nakamura A, Okamoto T, Ishimatsu A, Muramatsu T (1998) Lectin-induced enhancement of superoxide anion production by red tide phytoplankton. Mar Biol 131: 383-390

Paasche E, Bryceson I, Tangen K (1984) Interspecific variation in dark nitrogen uptake by dinoflagellates. J Phycol 20: 394-401

Shibanuma M, Kuroki T, Nose K (1990) Stimulation by hydrogen-peroxide of DNA-synthesis, competence family geneexpression and phosphorylation of a specific protein in quiescent BALB/3T3 cells. Oncogene 5:1025-1032

Shimada M, Nakai N, Goto $H$, Watanabe M, Watanabe $H$, Nakanishi M, Yoshimatsu S, Ono C (1991) Free radical production by the red tide alga, Chattonella antiqua. Histochem J 23:362-365

Shimada M, Kawamoto Y, Nakatsuka Y, Watanabe M (1993) Localization of superoxide anion in the red tide alga Chattonella antiqua. J Histochem Cytochem 41:507-511

Tanaka K, Yoshimatsu S, Shimada M (1992) Generation of superoxide anions by Chattonella antiqua: possible causes for fish death by 'Red Tide'. Experientia 48:888-890

Tanaka K, Muto Y, Shimada M (1994) Generation of super- 
oxide anion radicals by the marine phytoplankton organism, Chattonella antiqua. J Plankton Res 16:161-169

Watanabe M, Kohata K, Kimura T (1991) Diel vertical migration and nocturnal uptake of nutrients by Chattonella antiqua under stable stratification. Limnol Oceanogr 36: 593-602

Watanabe M, Kohata K, Kimura T, Takamatsu T, Yamaguchi S, Ioriya T (1995) Generation of Chattonella antiqua bloom

Editorial responsibility: Edna Granéli, Kalmar, Sweden by imposing a shallow nutricline in a mesocosm. Limnol Oceanogr 40:1447-1460

Zhou M, Diwu Z, Panchuk-Voloshina N, Haugland RP (1997) A stable nonfluorescent derivative of resorufin for the fluorometric determination of trace hydrogen peroxide: applications in detecting the activity of phagocyte NADPH oxidase and other oxidases. Anal Biochem 253: 162-168

Submitted: September 3, 2004; Accepted: January 19, 2005 Proofs received from author: April 14, 2005 